\title{
Article
}

\section{Mr. Kleks in space: science fiction for the end of state socialism}

\author{
Mazierska, Ewa Hanna \\ Available at http://clok.uclan.ac.uk/34502/ \\ Mazierska, Ewa Hanna ORCID: 0000-0002-4385-8264 (2021) Mr. Kleks in \\ space: science fiction for the end of state socialism. Studies in Eastern \\ European Cinema, 12 (1). pp. 83-94. ISSN 2040-350X
}

It is advisable to refer to the publisher's version if you intend to cite from the work. http://dx.doi.org/10.1080/2040350x.2020.1807091

For more information about UCLan's research in this area go to http://www.uclan.ac.uk/researchgroups/ and search for < name of research Group>.

For information about Research generally at UCLan please go to http://www.uclan.ac.uk/research/

All outputs in CLoK are protected by Intellectual Property Rights law, including Copyright law. Copyright, IPR and Moral Rights for the works on this site are retained by the individual authors and/or other copyright owners. Terms and conditions for use of this material are defined in the policies page.

\section{CLoK}

Central Lancashire online Knowledge www.clok.uclan.ac.uk

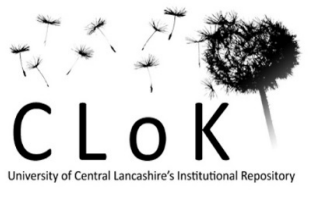




\title{
Mr. Kleks in space: science fiction for the end of state socialism
}

\author{
E. MAZIERSKA
}

[AQ0]

Ewa Mazierska

CONTACT Ewa Mazierska ehmazierska@uclan.ac.uk [AQ1]

\section{ABSTRACT}

Pan Kleks w kosmosie/Mr. Kleks in Space aka Mr. Blot in the Universe (Krzysztof Gradowski, 1988), is a genre hybrid, as testified by the fact that on the filmpolski.pl website, the largest Polish website listing films, it is classified as a 'musical film', 'film for children' and 'fantastical film'. I argue that its hybridity reflects the transitional period between state socialism and capitalism when the film was made and premiered. In my discussion I draw on the research on children's films and the concept of heterotopia. I also engage with the economic history of Poland during the last stage of state socialist rule.

Keywords: Pan Kleks w kosmosie ；Krzysztof Gradowski ; heterotopia ;Polish cinema ; science fiction ；children's film

This article discusses Pan Kleks w kosmosie/Mr. Kleks in Space aka Mr. Blot in the Universe (Krzysztof Gradowski, 1988), one of the most popular Polish films in the 1980s, in terms of box office results and one of the most international films ever made in Poland. My argument is that it is a genre hybrid, as testified by the fact that on the filmpolski.pl website, the largest Polish website listing films, it is classified as a 'musical film', 'film for children' and 'fantastical film'. I argue that its hybridity reflects the transitional period between state socialism and capitalism when the film was made and premiered. In my discussion I draw on research on genre cinema, including children's films and the concept of heterotopia. I also engage with the economic history of Poland during the last stage of state socialist rule.

\section{Production context of Mr. Kleks in space}

Mr. Kleks in Space is the third part of a four-part franchise, scripted and directed by Krzysztof Gradowski and devoted to the character of Mr. Kleks (Mr. Blot), a benevolent headmaster of Mr. Kleks' Academy, a boarding school for difficult boys, who during their time there experience fantastical adventures. The two first parts of Mr. Kleks' adventures, Akademia Pana Kleksa/Mr. Kleks' Academy (1984) and Podróże Pana Kleksa/Mr. Kleks’ Travels (1986), were adaptations of the books by Jan Brzechwa (1898-1966, real name Jan Wiktor Lesman), one of the most popular Polish children's authors. In total, Brzechwa wrote three books about Mr. Kleks and his pupils. The first book, Mr. Kleks' Academy, he created during the Second World War as a means to forget about the harsh reality of the occupation, not least because of his Jewishness he was particularly vulnerable to Nazi persecution.

One can observe many similarities between the stories about Mr. Kleks and the Harry Potter series, written by J. K. Rowling. Both series are based on the concept of a school run by wizards. Professor Dumbledore is like Mr. Kleks (who also bears the title of Professor) and the main child characters created by respective authors, Adaś Niezgódka and Harry Potter, are both 11-years old when their adventures begin, have bushy hair and are absent-minded. Both series of books are also very intertextual, drawing on many earlier works for children. For example, in the first part of Kleks, Mr Kleks' Academy, Adaś visits different fairy tales from which he 'borrows' gadgets needed in the Academy, such as matches from Hans Christian Andersen's The Little Match Girl. The connections between these two works even prompted a Polish critic, Marcin Kalita, to accuse Rowling on plagiarizing Brzechwa's classic on the grounds that she watched Mr. Kleks' Academy in Britain, where the film was shown (Kalita 2011). Although one cannot exclude Rowling's familiarity with the Polish children classic, more likely the similarities between them can be explained by the fact that both authors draw on a large repertoire of earlier children's literature, with wizards, pupils who outshine their masters and travels to places which are governed by a different logic than the one pertaining to the material world. 
Before embarking on his adventure with Mr Kleks, Krzysztof Gradowski made a number of documentary films. The majority of Polish filmmakers who started in this genre, attempted to move to fiction cinema for adults and Gradowski was no exception. The director himself admitted that Mr. Kleks' Academy was a consequence of the failure of his 'serious project' in the spirit of the Cinema of Moral Concern, which in the mid-1970s he proposed to Studio X, headed by the celebrated film director, Andrzej Wajda. Wajda then advised the budding director to make short films which are normally shown in cinemas before the main film. In this way Gradowski made Święty Mikołaj pilnie poszukiwany/Santa Claus Urgently Sought (1974), which is a story of two thieves who hide in an orphanage, while escaping the police. There they adopt the identity of Santa Claus. This film, addressed to children, gave Gradowski the idea of adapting Brzechwa's book for screen. However, it took almost ten years for this idea to be realized (Armata and Wróblewska 2014, 45-9), because Kleks required a large budget. It was the first Polish superproduction for children and therefore had to break certain modes of thinking about what children's film requires. At the time Gradowski embarked on this project, he faced little competition, because overtly commercial cinema was shunned by the bulk of Polish filmmakers, being seen as undermining their claim to artistic autonomy. ${ }^{1}$ Especially making profitable fantasy films did not translate into prestige, as demonstrated by Marek Piestrak's Test pilota Pirxa/The Test of Pilot Pirx (1979), and his subsequent SF and fantasy films, which, despite belonging to the most commercially successful films ever made in Poland both nationally and internationally, have been widely regarded as one of the worst Polish films ever made (Näripea 2014). However, in the 1980s, the high-art attitude in Poland started to give way to a more commercial approach, from which Gradowski benefitted.

This decade also saw a flourishing of Hollywood spectacular cinema as demonstrated by the successes of such films as Steven Spielberg's Raiders of the Lost Ark (1981), Indiana Jones and the Temple of Doom (1984) and E. T. the Extra-Terrestrial (1982). Ian Wojcik-Andrews, drawing on Robin Wood's research of cinema of the 1980s, argues that during this decade Hollywood cinema not so much made films specifically for children as addressed the viewers, irrespective of their age, as children, by using such motifs as naively optimistic narratives and simplistic ideologies, pronouncing that technology in the right (American) hands is good, while in the wrong hands is bad (Wojcik-Andrews 2000, 103-5). The reasons for making such films can be located in the shift in American politics, with the 1980 s being a conservative decade in comparison with the radical 1970s, and in the recognition that the cinema audience is getting younger. However, rather than appealing specifically to children and teenagers, directors such as Spielberg attempted to make films attractive to viewers of all ages. The aforementioned films are best described as 'family films' rather than 'children's films' (Bazalgette and Staples 1995). Gradowski himself admitted that he was inspired by Spielberg's productions and wanted to make films which successfully bridged the gap between SF films for adults and children (Armata and Wróblewska 2014, 47). It requires a considerable talent to talk to children and adults in a way which both categories find amusing. Inability to do so might lead to creating a fragmented film, with some parts appealing more to children, and others to adults. As I argue in due course, this was the case with Gradowski’s Kleks.

The influence of spectacular family films and especially E. T. on the first and subsequent films about Mr. Kleks can be detected not only in the film's text, but also in its promotion. To recuperate the considerable cost of the production of Mr Kleks' Academy, it was decided that its premiere would be preceded by a large advertising campaign and together with buying tickets to the film, the viewers would be able to purchase records with songs which featured in them, and other merchandise. The film thus became the centrepiece of an entire 'Kleks industry'. This strategy worked excellently, as demonstrated by the fact that for the first part of the Kleks franchise 14, 000,000 tickets were sold, making it the sixth most popular Polish film of all time, and the most popular Polish film of the 1980s (Wiśniewski 1989; Szymaszek 2014). It was claimed that in the 1980s Poland was in the grips of 'kleksomania', reflecting not only the previously mentioned factors, such as 're-juvenation' of the film audience at the time (Lubelski 2009, 444), but also of a deep economic crisis Poland suffered in the 1980s. Gradowski's screening of Mr. Kleks' adventures arguably allowed its viewers an imaginary escape from the grey reality of queues for groceries, similar to the way it helped Brzechwa to escape the harsh reality of the Nazi occupation.

Of the three films about Mr Kleks which Gradowski directed in the 1980s, the first part was the most successful commercially and artistically. The second part was watched by over 8,000 000 people and Mr. Kleks in Space by over 4,000,000 viewers (Szymaszek 2014). We thus observe a steady decline in the audience's interest in the Kleks project. Equally, the third part attracted cooler reviews than the previous two instalments (Wiśniewski 1989). However, such a decline is expected in the case of sequels, as well as in the context of declining cinema audiences in the 
1980s. Moreover, even though Mr. Kleks in Space attracted less than one third of the audience of Mr. Kleks' Acade$m y$, it still belonged to the most popular films of the 1980s.

As already mentioned, Mr. Kleks in Space was inspired predominantly by fantasy films produced in the West. At the same time, it was a very socialist film due to being a coproduction with socialist countries, Czechoslovakia (Studio Koliba) and Soviet Union (Mosfilm). Some of the episodes were shot on the territory of the Soviet Union, such as the airport in the capital of Armenia, Yerevan and botanical gardens in Batumi in Georgia. Czech and Soviet technicians were used to produce futuristic effects which, predictably, even in the 1980s, looked somewhat dated, as if confirming the view that by this point the socialist world lagged behind the West to such an extent that it had no chance to survive much longer. As a product of collaboration within the socialist bloc, Mr. Kleks in Space was a typical Polish and Eastern European SF film, especially as high budget films were concerned, for example Der schweigende Stern/First Spaceship To Venus (Kurt Maetzig, 1960), which was a Polish-East German coproduction and Piestrak's Pirx. Its subsequent popularity in the whole socialist bloc and especially in the Soviet Union, where, according to the director, there were 3000 fan clubs of 'Mr. Kleks' (Armata and Wróblewska 2014, 47), suggests that such a strategy worked well. By deciding that Mr. Kleks would be a 'socialist affair', rather than seeking partners on the other side of the Iron Curtain, Gradowski and his collaborators bucked the dominant economic trend of the 1980s, which consisted of, on -09-0880 one hand, increased imports from non-socialist countries and, on the other hand, trying to sell their products in the West. In hindsight, the economic strategy behind Gradowski's project was sound, because the deep economic and subsequently political crisis, which befell the socialist bloc in the 1970 and deepened in the 1980s was to a large extent caused by its unsuccessful engagement with Western economies (Berend 1996, 222-53).

While the first two parts of Gradowski's trilogy follow closely Brzechwa's books, Mr. Kleks in Space is based on the original script by Gradowski. The director-scriptwriter borrowed from Brzechwa only the character of Kleks (whose role is reduced in comparison with the two books) and the idea of characters visiting different worlds. The relatively moderate success of this part of franchise is often explained by there being too little of Mr. Kleks. This was due to the fact that Piotr Fronczewski, the charismatic actor cast in this role, by this point was tired of being Mr. Kleks, and he was not replaced by a character of similar stature.

The fact that the third part of Mr. Kleks' adventures is set in space can be regarded as a logical conclusion to his stories. First the wizard worked in his academy, then he embarked on travels to different corners of the world and, finally, he left the Earth to explore the cosmos. But Gradowski himself explained the SF character of his film by the fashion for electronics, which swept Poland in the 1980s (Armata and Wróblewska 2014, 48). In the 1980s young people started to be interested in computers and computer games. This was reflected in the immense success of 'Bajtek', one of the first Polish magazines devoted to electronics, set up in 1985 and addressed to the newcomers to the computer world, including children and teenagers. 'Bajtek"s mission was to tackle computer illiteracy and, predictably, it projected computers as innocuous and friendly machines, whose mission is to make human life easier. Gradowski could not ignore this attitude - his film was addressed to the 'Bajtek Generation'. At the same time, in common with some Western films of the 1980s, such as TRON (Steven Lisberger, 1982), which depicted the computer as a dangerous place where one can be imprisoned, and lose one's human characteristics, it also plays with the concept of the virtual universe as a dangerous place.

\section{The future like the past}

Mr. Kleks in Space consists of two parts: Porwanie Agnieszki (The Kidnapping of Agnieszka) and Misja Voltana II (The Mission of Voltan II). Kidnapping of Agnieszka begins with a scene in a Warsaw orphanage, which prepares for Christmas celebrations. Its peak is meant to be a meeting with Jack Bromowski, who grew up in this place, but in due course became an American businessman, earning millions of US dollars thanks to setting up his own electronic firm, MBM (a nod to IBM). Such representation of the 'returned' as a hero reflects on the common dream of Poles emigrating to the West - to set up their own business and become wealthy. It also testifies to the fact that this film was made at a time when leaving Poland was no longer seen by the authorities as an act of betraying one's country and help from the West was appreciated as a means to alleviate the country's economic crisis. This new attitude, which began in the 1970s, when the West-friendly Edward Gierek became the Party leader, is also testified by Jack being greeted by a journalist working for state television, as if he was a celebrity. The meeting proves awkward. The TV journalist, played by Anna Frankowska-Teter, a real TV journalist, popular at the time, speaks rather poor English, before switching to Polish, which is a language both speakers prefer to use. Such awkwardness around English (most 
likely unintended by the scriptwriter-director) can be symbolic of the Polish and Eastern European attempts (pertaining to this and the later period) to catch up with the West, but failing to do so.

In his book Orphans of the East: Postwar Eastern European Cinema and the Revolutionary Subject Constantin Parvulescu argues about the importance of the character of an orphan in Eastern European cinema. This reflected a high proportion of orphans left after the Second World War in this part of Europe and it being metaphorically 'orphaned' by the West, which left its fate in the hands of the Soviet Union and the communist regimes. Parvulescu claims that the role of the orphan kept changing, at times pointing to the progressive politics of Eastern Europe's regimes which allowed the orphans to achieve professional success and self-fulfilment (Parvulescu 2015). The question arises what kind of orphans Gradowski shows in his film and what these orphans signify. They are by no means destitute, but rather well looked after and as happy as parentless children can be. As a metaphor, they can stand for Poland being orphaned again in the late 1980s, due to Mikhail Gorbachev's decision for the Soviet Union to abandon its role as guarantor of the socialist order in satellite countries, granting them more sovereignty, largely due to the economic burden of such heavy engagement in the region. 'Orphaned' by their Eastern 'fathers', Polish children are presented as waiting for the benefactors from the West, bringing them advanced technology and hope.

Jack is indeed bringing a gift to the orphans - the most advanced computer in the world. This precious gift is contrasted with the outmoded technology used by Poles in their daily lives. The orphanage headmaster Gładysz, together with another employee, driver Jarząbek, travel to the airport in an old lorry, which breaks down on the way and they almost miss the distinguished visitor. During their journey they comment that their vehicle is unsuitable to carry such a precious gift. The clash between the Western state of the art technology and a Eastern clumsy vehicle used to carry it can be seen as a metonymy of the economic reality of this period. As Ivan Berend observes, in the late 1970s and the 1980s the West experienced the 'fifth industrial revolution', which

gradually transformed technology, and indeed created a new stage of civilization, the post-industrial or communication epoch... As with textiles two hundred years before, electronic became the herald of the new age. The Soviettype modernization model remained light years behind the requirements of the new technological era. Central and Eastern Europe conserved its antiquated technology. It may be compared to a situation of attempting to adjust to the nineteenth-century Industrial revolution without having railroads. (Berend 1996, 226)

More specifically, carrying a computer in a battered lorry can be regarded as a metaphor of the situation of late state socialism, when Poland purchased many licenses from the West for products which turned out to be unsuitable for the country due to being, for example, too delicate. Again, this situation points to the fact that technological progress, to be successful, has to be achieved in many fields at the same time.

Nevertheless, the computer is delivered safely to the orphanage. There Jack tells the children that because it is Christmas, when animals speak with human voice, the computer will also talk to them. Presenting the computer as a pet is in the spirit of the 'Bajtek' computer magazine, whose purpose was to 'domesticate' these alien creatures. Indeed, the computer talks, but even more importantly it projects a world as it will look in 25 years. My argument is that this world includes elements of the past, the present and the future, which do not coalesce into a coherent whole and characters from the present appear in new disguises. This future can be seen as a heterotopia: a space outside normal experience.

Michel Foucault, who introduced this concept in 1967 in a lecture, later appropriated by many postmodern thinkers, defines heterotopias as 'counter-sites, a kind of effectively enacted utopia in which the real sites, all the real sites that can be found within the culture, are simultaneously represented, contested, and inverted. Places of this kind are outside of all places, even though it may be possible to indicate their location in reality' (Foucault 1998, 231). As examples of heterotopia Foucault mentions prisons and psychiatric hospitals, as well as colonies, brothels and, most importantly, ships (ibid., 232-33) and lists five principles of heterotopias, of which the most relevant to my analysis are the third and fourth principles. According to the third principle, 'the heterotopia is capable of juxtaposing in a single real place several sites that are themselves incompatible' (ibid., 233). Foucault mentions theatre and film, when 'on a two-dimensional screen, one sees the projection of a three-dimensional space' (ibid.). However, while every film projection is heterotopian in the sense described by Foucault, there are films which are heterotopian at the level of their diegesis: the world they represent is unrealistic and incongruent. There are certain types of film which are conducive to creating heterotopias, such as international coproductions and science fiction films (Mazierska 2012), and Gradowski's film belongs to both of these categories. The fit between coproductions and heterotopias reflects the 
fact that involving more than one national team often requires juxtaposing ideas and images which are normally incompatible ${ }^{2}$. Science fiction films are natural candidates to producers of heterotopias because they show people travelling across huge distances and time zones, which brings me to Foucault's fourth principle, namely that heterotopias are heterochronies - they are linked to slices of time. 'The heterotopia begins to function at full capacity when men arrive at a sort of absolute break with their traditional time. The situation shows us that the cemetery is indeed a highly heterotopic place since, for the individual, the cemetery begins with this strange heterochrony, the loss of life, and with this quasi-eternity in which her permanent lot is dissolution and disappearance' (ibid., 234).

It can be argued that all genre films are heterotopian due to their continuous development and impurity. As Steve Neale noted: 'Any film (like any text, utterance or instance of representation) can participate in several genres at once. In fact, it is more common than not for a film to do so (Neale 2000, 25). However, genre films normally strive for harmony and order, for blending seamlessly elements of different genres. 'Heterotopian eye' sees the world in terms of rupture and the impossibility to impose the order on the received world. This aspect of heterotopia is elaborated by Foucault in The Order of Things, where he maintains that

Heterotopias are disturbing, probably because they secretly undermine language, because they make it impossible to name this and that, because they shatter or tangle common names, because they destroy 'syntax' in advance, and not only the syntax with which we construct sentences but also that less apparent syntax which causes words and things (next to and also opposite one another) to 'hold together'. (Foucault 2002, xix)

In Foucault's definition, heterotopias are related to all the other sites, but in such a way as to suspect, neutralize, or invert the set of relations that they happen to designate, mirror, or reflect $(1998,235)$. Such a description suits well the spaces presented in Gradowski's film, which are located on several different planets and in outer space. Moreover, their ontological status is uncertain. What we see in the bulk of the film comes across as a story unfolding in the material reality, but the beginning and the end of the film suggests that this is only a dream or a film projected on a computer screen, in the way films are watched these days. The introduction and the coda thus undermines the reality of the diegesis, but also comes across as somewhat unreal due to the events unfolding there and the casting strategies employed by Gradowski.

The dream/film begins with the journey of a space ship, which in Triangle of Titans is captured by the Great Electrician, a mad scientist who moved from the Planet of Inventors to Mango, a planet governed by the benevolent Manuel Carmello de Bazar, whom the Great Electrician effectively overpowered. This motif is clearly borrowed from Star Wars, whose narrative and spectacular dimension was one of Gradowski's sources of inspiration. The Great Electrician is an ardent enemy of Mr. Kleks due to a previous conflict. On Mango the Great Electrician works on a project of 'phantomisation', whose purpose is to dissolve material objects into elementary particles, so that they can be easily transported and reassembled when they reach their destination. It is worth mentioning that 'phantomisation', whose filmic origins probably lie in TRON, would be used in another Polish science fiction film, made several decades later, Avalon (2001), directed by Mamoru Oshii.

In the role of Manuel is cast Jerzy Smoleń, a comedy and cabaret actor, who during his career tended to portray somewhat thwarted men, whose vis comica was based on the viewer's observation that they in fact have something important to say, unlike their mightier, self-important and more talkative interlocutors. In the part set in the present, Smolen played driver Jarząbek, who brought the computer from the airport to the orphanage in his dilapidated vehicle. 'Bazar' in his name is symbolic of the 1980s, when the black market in Poland was flourishing, partly due to the acute shortages of consumer goods and partly because of the government turned a blind eye on the illegal ways people used to overcome these shortages. It can even be suggested that in this period the authorities themselves revealed a 'bazar mentality', being preoccupied with preserving their material privileges rather than upholding socialist ideology. 'Carmello' suggests that the bearer of such a name is sweet and innocuous. Despite his Spanish-sounding name, Manuel can be seen as epitomizing politically crushed yet surviving Poland of the 1980s: Poland of small people. At the same time, the foreign-sounding Manuel Carmello de Bazar adds a heterotopian undertone to the Planet Mango.

The Great Electrician is played by Henryk Bista, who specialised in the roles of vicious and demonic men. As the owner of elaborate gadgets whose purpose is to spy on Manuel, the citizens of Mango and the entire universe, and kidnap space ships, he might be regarded as a symbol of the Soviet Union, with its ambition of winning the Star Wars. Although the Great Electrician is the chief black character in the film, he is not particularly dangerous and he even shows some humane traits as he intends to kidnap a cute little girl from the Earth not to please himself or conduct vicious experiments, but for Carmello, who would like to have a daughter to love and pamper. 
Manuel's wife, Linella, is played by Maryla Rodowicz, the greatest Polish female pop star of state socialism. Noisy and taller than Manuel, she thwarts the diminutive Manuel. Although she is plump, while Manuel is slim, she urges her husband not to eat so much candy because he will end up overweight. Linella has artistic ambitions as her dream is to be a star of a rock opera and one conjectures that she intends to use state resources to further her career. Manuel and Linella's relationship, with the man being merely in office, rather than in power, and the woman taking care of the household, can be regarded as symptomatic of the dominant ideology of the 1980s, when many popular cultural texts conveyed the fear of women, including in the genre of science fiction, such as Seksmisja/Sex Mission (Juliusz Machulski, 1983) and the radio series, Matriarchat/Matriarchy (1978), written by Marcin Wolski. Manuel himself might want to have a daughter to balance the effect of his noisy and overwhelming wife.

The girl whom he eventually chooses to kidnap, the titular Agnieszka, lives on Earth and attends the School of Future whose patron is the most famous Polish SF writer, Stanisław Lem. No doubt evoking Lem was a nod to the adult viewers of Kleks, rather than children. Children work there on computers rather than writing in their copybooks which was still the norm in the 1980s not only in the East, but also in the West, and many functions of the teachers are performed by a robot Bajtek, whose name is a reference to a popular computer journal, as previously mentioned. The school harks back to Stalinist times, as discipline and uniformity are presented as the cornerstones of a good education. Yet, the headmaster, nicknamed Kudłacz, played by Emilian Kamiński, who in the present part was cast as Gładysz, the headmaster of the orphanage, with his shaggy hair ('kudłacz' means 'shaggy'), leather tracksuit, golden chain and gestures, particularly when he comes down from his office and is lit by a reflector, brings to mind a pop star, rather than a Stalinist, ideology-driven dictator. The YouTube users compared him also to Edward Scissorhands from the famous film by Tim Burton. Kudłacz is not particularly benevolent, but neither is he a tyrant in his everyday behaviour and the school came across as a reasonably happy place, where children are well looked after and, contrary to the school's ethos, independent. The memory of Kudłacz's computer, which one of the pupils hacks, is full of fairy tales, which likens him to Mr. Kleks, who was also a collector of fairy tales.

The school is difficult to 'map' - there is no establishing shot, which will present it in relation to other places. We do not know in which country (countries might be abolished by this point, as is the case in many SF films) or part of the Earth it is located, and how its specific parts relate to each other. By and large, the school comes across as a patchwork of places which do not constitute a visible coherent whole, and which convey a set of contradicting meanings: a model heterotopia. Furthermore, the school is neither utopian nor dystopian, because on the surface it presents a 'totalitarian', Stalinist image, but inside is a place where children do what they want and are very creative. This incoherence can be regarded as reflecting on Poland of the 1980s, which ostensibly experienced one of the most brutal acts of totalitarian power, the imposition of martial law, but under the surface of numerous restrictions enjoyed much freedom.

The narrative equilibrium is broken by the kidnapping of Agnieszka, cast in the main role in The Princess and the $P e a$, staged by children as a way to cheer their headmaster, angered by one of them hacking their computer. The remaining part of The Kidnapping of Agnieszka is taken by an attempt to rescue the girl by her class mate, Groszek (which means 'pea'), with the assistance of the friendly Bajtek. Bajtek suggests that in order to fulfil their mission they have to bring in to their team a robot of the third generation, which is able to think for itself (hence can be regarded as possessing artificial intelligence), unlike Bajtek, who is a more primitive model. Paradoxically, in order to find this advanced robot, Groszek and his class have to visit not a state-of-the-art factory, producing such advanced equipment, but a scrapyard, where the most advanced robots are disposed of. The history of technology, as presented in this film, is thus moving backwards. This paradox can be seen in the context of the period of late state socialism, when many countries of the Soviet Bloc, including Poland, suffered acute economic crisis and had to abandon ambitious programmes of industrial and technological expansion and return to a more primitive state of development (Berend 1996, 222-253). As a result, much of the advanced equipment had to be thrown away and became the object of scavenging, as we also see in Gradowski's films where the rubbish heap with the old robots is invaded by various thieves hunting for scrap metal.

Luckily for the team trying to rescue Agnieszka they find one fully functioning robot, called Silver, who advises Groszek to seek the assistance of Mr. Kleks, who once already saved Silver's life. Mr. Kleks now lives in the only nature reserve on Earth. This can, again, be read in the context of the state socialist economy, known for its high level of pollution and wasteful use of natural resources. Eventually a team is assembled, which also includes Groszek's father, the experienced pilot Max Benson, who bears his own grudge towards the Great Electrician. Max is played by 
Jan Jankowski, who was cast as Jack Bromowski in the contemporary part of the film. We can thus gather that the rescue operation cannot succeed without bringing together the past (Mr. Kleks) and the future (a foreigner and artificial intelligence). The spaceship used by this motley heterotopian crew, Voltan II, is described as a somewhat anachronistic model, but one whose advantage over the newer machines lies in its relative simplicity and reliability. Again, such praise of a 'simple model' can be seen as a way of comforting the Poles who were left behind in the technological race by suggesting that they will still be able to 'reach the stars' in their old-fashioned vehicles because they are simpler and more robust.

The first part finishes with Voltan II's departure and the second one is entitled The Mission of Voltan II. It begins with a voice-over telling the story of a mysterious landing of a space ship in $17^{\text {th }}$-century China, which left behind a gift for the Ming Dynasty: a pagoda-shaped box containing something mysterious. The motif adds to the heterotopian character of the film, as it both orientalises the narrative and transports it into a more distant past than the Stalinist period. The box also links this part of Mr. Kleks' adventures to Klatwa doliny węży/The Curse of Snakes Valley (1987), the second part of Marek Piestrak's 'Estonian Trilogy', set on the border between Vietnam and Laos, where a pilot also finds a mysterious box in a Buddhist temple. In both films introducing such a motif means that the protagonist travels back in time, to Mr. Kleks's youth in this case, who recollects this adventure during his travel in the Voltan II. It transpires that he was then a witness of passing the information about the box from the Chinese monarch to his physician, who passed it further to the then young Kleks. We can thus gather that Mr. Kleks' life spans several centuries and that he ages, but much slower than ordinary people.

At the same time, Mr. Kleks learns from Max Benson that in his youth the pilot was also involved in recovering the pagoda-shaped box. Max's story is cloaked in the Cold War narrative of espionage and competition between two major political blocs, operating in different parts of the universe, which can easily be seen as standing for the two main political blocs on Earth: capitalism and state socialism. Max's mission is frustrated by the attacks of some alien creatures, but he manages to hold on to the box and reach a base adorned with a neon sign 'IFB' (a nod to 'FBI'). There he is attacked again, but manages to save the precious box and as a reward is promoted to the post of commander. The attackers remind us of the various strange creatures living in different parts of the 'Gradowski universe', such as the nature reserve, where Mr. Kleks dwelled when he was first approached by the children, or the Planet Mango, governed by Carmello de Bazar. The only difference is that the other creatures are colourful, while Max's attackers are black. The similarity between these creatures, which most likely results from the limited resources for design or Gradowski's ambition to design some of them, adds to our disorientation in this filmic universe, which pertains to the heterotopian experience.

The promotion Max receives from the head of the army and prime minister, whose clothes, demeanour, and the spaces they occupy, bring to mind the solemnity of the Soviet political protocol. In conversation with Max, Mr. Kleks reveals that the box contained a map of the universe, showing all the places inhabited by creatures similar to humans. Why such a map is a subject of bitter fighting of different forces throughout the centuries is difficult to guess, especially as at the time when the future part of Gradowski's film is set, everybody seems to know where the foreign civilizations are to be found. We can gather that the pagoda-shaped box is just one of many motifs borrowed by Gradowski from earlier SF and fantasy films to fill the second part of Mr Kleks in Space.

The Great Electrician does everything he can to prevent the passengers of Voltan from rescuing Agnieszka, but to no avail. They safely reach Mango thanks to the phantomisation device which Agnieszka takes over from the Great Electrician. It allows her to bring the Voltan's crew to Mango and get rid of the Great Electrician. He is spirited away from Mango with ease, which brings to mind the ease, with which Poland rid itself of its communist leaders at the end of the 1980s. However, he appears again in the last episode of the film, when the action moves back to the present. The Great Electrician's new incarnation is that of a crook trying to steal a computer from the orphanage with the assistance of another crook during Christmas celebrations. This motif harks back to Gradowski's first film for children, the short Santa Claus Urgently Sought.

Before the children's dream or the film within a film ends, the narrative of rescuing Agnieszka gives way to a spectacle in the style of entertainment typical for Polish television of the 1980s, with its focus on visual excess. Such a style produces an effect of carnival, of dancing on the 'sinking Titanic', which can be seen as a reaction preceding the introduction of austerity measures in the early 1990s. The two main entertainers in this carnivalesque excess are played by two popular Polish singers: the previously mentioned Maryla Rodowicz, a superstar of the socialist period, and Beata Kozidrak from the band Bajm, which gained prominence in the 1980s and was one of the most popular 
Polish bands of the 1990s. Kozidrak's appearance in the end of the film suggests that she is taking over the baton from the older Rodowicz as the 'queen of entertainment'. Rodowicz, however, is allowed to stay on the scene, even if in a less prominent role, suggesting that the shift from the 1980 to the 1990s is not dramatic, but gradual. Rodowicz and Kozidrak's presence strengthens the heterotopian character of the film because these stars (especially Kozidrak) are not fully integrated into the film's narrative. They play themselves, pop stars, rather than performing any specific roles. Kozidrak does not even have any speaking parts - she just walks onto the stage and dancing and singing in her typical 'sexy' style.

\section{Conclusions}

A question arises why Gradowski included in his film so many different elements which do not fit together, but produce discord. One possible answer is his inability to come up with an original and coherent story, while feeling the urge to write the script himself, widely regarded as the weakest aspect of Mr. Kleks in Space. Such a desire reflects on the Polish cinema's lack of high quality scriptwriters and the ambition of the majority of directors to make films based on their own scripts. The special challenge, in this case, was to make a film appealing to both adult and children's tastes. Unlike the American films mentioned above, which tried to bring the two audiences to a common denominator by infantilising the adults, Gradowski separates them, for most of the films addressing the young audience, but on occasions planting something which is meant to appeal to the adults, such as political subtext and pop stars. It could be argued that in this respect he was less talented than Brzechwa, whose books about Kleks are appreciated also by adult readers. For this reason Gradowski's earlier parts of Kleks fit better the concept of family cinema than Mr. Kleks in Space.

It appears as if deprived of a literary source of high quality and trying to attract as wide an audience as possible, Gradowski put in his film everything he was able to lift from other films which seemed to be relevant to his project, including his previous film and those by Piestrak, and used his own experience of living in Poland in the 1980s, as well as a collective memory of life in postwar Poland. In this world a supposedly totalitarian school is governed by a punk and advanced technology is discarded, because people believe simpler machines are more functional, even for space exploration. People and countries spy on each other as throughout the entire period of Cold War, but nobody remembers the purpose of this espionage. I argued that despite its shortcomings or perhaps thanks to them, Mr. Kleks in Space reflects well on the last years of state socialism in Poland, where many things were done as before, but due to custom, rather than conviction, and 'spectacle' was used by the authorities to cover up the lack of a convincing 'narrative' of happiness and progress.

It also worth adding that while in the 1980s making a film for children or families was in Poland a sign of not being quite up to the job of a serious filmmaker, in the subsequent decade this attitude changed, as demonstrated by the fact that some leading Polish auteurs embarked on making films fitting this genre. In 1993 Agnieszka Holland directed in Hollywood The Secret Garden; in 1996 Andrzej Wajda made Panna Nikt/Miss Nobody. Both films are also adaptations of popular books, respectively by Frances Hodgson Burnett and Tomek Tryzna, with the latter being one of the biggest bestsellers in Poland of the 1990s. Another renowned Polish filmmaker, Roman Polanski tried to make inroads into family cinema, twice, in 1986 directing Pirates and in 2005 Oliver Twist. All these films, however, seem marginal in the careers of the respective directors and some are seen as their weakest films.

As a full-length SF family film, Mr. Kleks in Space remains a unique endeavour in Polish cinema, reflecting not so much on the lack of tradition of making SF films, but family cinema and the low status such cinema occupies in Polish film criticism. The perceived low quality of Kleks, especially in the light of its high budget and difficulties producing it, does not encourage Polish filmmakers to follow in Gradowski's footsteps. [AQ2]

\section{Disclosure statement}

No potential conflict of interest was reported by the author. [AQ3]

1. The organization of the Polish film industry, with semi-autonomous units, financed by the state, which covered the deficit of the making high-art, yet unprofitable films, fostered such anti-commercial approach. 
2. The contemptuous term 'Euro-pudding' reflects the conviction that it is impossible to create a convincing film, reflecting on more than one national culture; that it will be effectively a heterotopia.

\section{References}

Armata, Jerzy, and Anna Wróblewska. 2014. Polski film dla dzieci i mlodzieży. Warszawa: Wydawnictwo Kino. [AQ4]

Bazalgette, Cary, and Terry Staples. 1995. "Unshrinking the Kids: Children's Cinema and the Family Film." In In front of the Children: Screen Entertainment and Young Audiences, edited by Cary Bazalgette and David Buckingham, 92-108. London: British Film Institute.

Foucault, Michel. 1998 [1967]. "Of Other Spaces.” trans. Jay Miskowiec, In The Visual Culture Reader sec. edition, edited by Nicholas Mirzoff, 229-236. London: Routledge.

Foucault, Michel. 2002 [1966]. The Order of Things: An Archeology of the Human Sciences. London: Routledge Classics.

Kalita, Marcin. 2011. “Pan Kleks kontra Harry Potter. To plagiat?” Nowiny 24, 30 January. accessed 28 April 2015. http://www.nowiny24.pl/apps/pbcs.dll/article?AID=/20110130/WEEKEND/826053790

Lubelski, Tadeusz. 2009. Historia Kina Polskiego: Twórcy, Filmy, Konteksty. Katowice: Videograf II.

Mazierska, Ewa. 2012. "International Co-Productions as Productions of Heterotopias." In A Companion to Eastern European Cinemas, edited by Anikó Imre, 483-503. Oxford: Wiley-Blackwell.

Näripea, Eva. 2014. "Postcolonial Heterotopias: A Paracinematic Reading of Marek Piestrak's Estonian Coproductions." In Polish Cinema in a Transnational Context, edited by Ewa Mazierska and Michael Goddard, 115-133. Rochester, NY: University of Rochester Press.

Neale, Steve. 2000. Genre and Hollywood. London: Routledge.

Parvulescu, Constantin. 2015. Orphans of the East: Postwar Eastern European Cinema and the Revolutionary Subject. Bloomington and Indianopolis: Indiana University Press.

Szymaszek, Karolina. 2014. “Trylogia filmowa o przygodach Pana Kleksa.” Praca licencjacka, Uniwersytet Gdański, Wydział Filologiczny, Filologia polska, Gdańsk 2014.

Wiśniewski, Cezary. 1989. “Do Trzech Kleksów Sztuka.” Film, 1, p. 14.

Wojcik-Andrews, Ian. 2000. Children's Films: History, Ideology, Pedagogy, Theory. New York: Garland.

\section{AUthor QUeRIES}

Query: AQ0: Please review the table of contributors below and confirm that the first and last names are structured correctly and that the authors are listed in the correct order of contribution. This check is to ensure that your names will appear correctly online and when the article is indexed.

\begin{tabular}{|l|c|l|l|}
\hline \multicolumn{2}{l}{ Sequence Prefix Given name(s) } & Surname & Suffix \\
\hline 1 & Ewa & Mazierska \\
\hline
\end{tabular}

Author Response: Ok

Query: AQ1:Please provide affiliations for all authors.

Author Response: University of Central Lancashire

Query: AQ2:Please provide the short biography of the author in the Notes on contributor section.

Author Response: Ewa Mazierska is Professor of Film Studies at the University of Central Lancashire. She published over thirty monographs and edited collections, including Poland Daily: Economy, Work, Consumption and Social Class in Polish Cinema (Berghahn, 2017). 
Query: AQ3:The disclosure statement has been inserted. Please correct if this is inaccurate.

Author Response: Ok

Query: AQ4:Please provide complete details for (Berend 1996) in the reference list or delete the citation from the text.

Author Response: Berend, Ivan T. 1996. Central and Eastern Europe, 1944-1993. Detour from the Periphery to the Periphery. Cambridge: Cambridge University Press. 